\title{
Gil Vicente e a arte de pregar: o Auto dos Mistérios da Virgem ou da Mofina Mendes ${ }^{1}$
}

Maria do Amparo Tavares Maleval Universidade do Estado do Rio de Janeiro

\section{- Considerações preliminares}

A principal evidência norteadora do nosso enfoque da obra vicentina é a de que Gil Vicente, considerado o 'criador' do teatro português, foi um grande conhecedor dos sermões medievais, chegando mesmo a escrever alguns espécimes sérios ou jocosos, mas sempre revestidos de caráter moralizante. $\mathrm{O}$ mais completo e primeiro deles foi o paródico Sermão de Abrantes, encomendado pela Rainha D. Leonor, $1506 .{ }^{2}$ Também ligada a esse gênero é a 'fala' de Gil Vicente aos padres, que atemorizavam o povo com a profecia de terremotos apresentados como castigo divino, inserida na carta que enviou

${ }^{1}$ Estudo realizado sob os auspícios do CNPq (bolsa de Produtividade em Pesquisa) e do Prociência UERJ. Retoma artigo de minha autoria intitulado "A propósito de um título vicentino" (1983), que foi uma das minhas primeiras publicações.

${ }^{2}$ Foi "pregado em Abrantes ao muito nobre rei dom Manoel, o primeiro do nome, na noite do nascimento do ilustríssimo infante dom Luís", em 1506 (VICENTE, 2002, vol. II, p. 447). 
a Dom João III em $1531 .{ }^{3}$ Outro sermão, inicialmente burlesco, igualmente re(a)presentado a este rei, no Natal de 1534, é o discurso aparentemente amalucado com que um frade inicia o Auto dos Mistérios da Virgem, mais conhecido como Auto da Mofina Mendes, ${ }^{4}$ que será objeto de nossa reflexão no presente estudo.

Considerando que a ars praedicandi medieval deu sequência à retórica clássica, com importações da tradição exegeta judaica do Velho Testamento e dos ensinamentos metadiscursivos e práticos de Jesus Cristo e seus discípulos, o estudo das técnicas dos sermões e dos tratados que as sistematizam apresenta fundamental importância para a observação do processo interativo ocorrido entre os discursos que compõem o Auto escolhido (e não só).

Mesmo que de forma sucinta, faz-se necessário recordar que o sermão medieval, na definição de Alain de Lille, constituía "um ensino público e coletivo dos costumes e da fé, apoiado na razão e fundamentado em autoridades, tendo em vista a instrução dos homens". ${ }^{5}$ E sua técnica, segundo Thomas de Galles, consistia em, "após a invocação do auxílio divino, na exposição de um tema escolhido e sua divisão em várias partes convenientemente concordantes entre si, com a finalidade de fornecer um ensinamento da doutrina católica ao intelecto e de inflamar de

3 ..." estando Sua Alteza em Palmela, sobre o tremor de terra, que foi a 26 de Janeiro de 1531" (VICENTE, 2002, vol. II, p. 479).

${ }^{4}$ Obra re(a)presentada "ao excelente príncipe e muito poderoso rei dom João terceiro, endereçada às matinas do Natal, na era do Senhor 1534" (VICENTE, 2002, Vol. I, p. 111).

5 "Praedicatio est, manifesta et publica instructio morum et fidei, informationi hominum deserviens, ex rationum semita, et auctoritatum fonte proveniens" (P.L., t. 210, col. 11. Apud DAVY, 1931, p. 3; a tradução apresentada acima é nossa). 
caridade os corações" ${ }^{6}$ Delineia-se já a partir dessas definições primeiras da prédica medieval a sua preocupação de comunicação com o auditório, objetivando ensinar e converter os ouvintes para a prática de ações virtuosas. Outra não é a intenção das 'moralidades' vicentinas, como veremos na escolhida para análise, que é um dos mais destacados 'autos de devoção' do autor.

Vale lembrar, com Joaquim de Carvalho (1948), que a divisão do tema do sermão podia "ser intra, isto é, intrínseca e abstrata, normalmente praticada só perante auditórios ilustrados, e extra, isto é, assente em imagens, representações sensíveis, exempla, etc., dirigida a auditórios populares, isto é, a pessoas ignorantes" ${ }^{7}$ O que é da maior importância para o entendimento das moralidades vicentinas, dirigidas a auditórios heterogêneos em termos de erudição - daí a necessidade de recorrerem à concretização de idéias abstratas através da alegoria e de outros recursos retórico-poéticos.

\section{Os Autos de devoção vicentinos}

Os Autos de devoção de Gil Vicente ${ }^{8}$ ocupam lugar de destaque nas cerca de cinqüenta peças por ele escritas e representadas entre os anos de 1502 e 1536. O dramaturgo, cujas datas e locais de nascimento (à roda de 1465, possivelmente em Guimarães) e morte (em ou após 1536) são imprecisas,

\footnotetext{
6 "Praedicatio est, invocato Dei auxilio, propositi thematis dividendo et concordando, congrue data et devota expositio, ad intellectus catholicam illustrationen et affectus caritativam inflammationem" (Apud DAVY, 1931, p. 31; traduzimos acima).

${ }^{7}$ CARVALHO, 1948, p. 13.

${ }^{8}$ Abordamos de forma mais ampliada a questão genológica do teatro vicentino em estudo anterior. Cf. MALEVAL, 1992, p. 179-190.
} 
pertenceu à geração de $\mathrm{D}$. João II e abrilhantou com seus autos a corte de D. Manuel, sob a proteção da Rainha Velha, D. Leonor, estendendo ainda a sua atividade à corte de D. João III. ${ }^{9}$ Assistiu, pois, à formação e apogeu do império português no além-mar, bem como ao início do seu declínio, tendo como principal mecenas a franciscana rainha.

Considerado o 'criador do teatro português', em seus autos revitalizou e aprimorou elementos do teatro medieval, religioso (mistérios, moralidades e milagres) ou profano (sermão burlesco, farsas). Para eles confluíram a herança das procissões e momos, das cantigas, baladas e hinos, das novelas de cavalaria e de figuras das mitologias cristã e clássica, condensando a tradição corrente à época - de transição para o renascimento.

A sua obra, compilada com algumas falhas pelos seus filhos Luis e Paula Vicente, somente seria publicada postumamente, em 1562. Em vida, Gil Vicente teria publicado textos em folhas volantes e trabalhado na preparação da edição completa dos mesmos. Então, os dividira em 'comédias', 'moralidades' e 'farsas', divisão que não foi seguida pelos seus filhos, que os reuniam sob as rubricas 'autos de devoção', 'farsas', 'comédias' e 'tragicomédias'. Tais classificações têm sido questionadas no correr dos séculos, sendo que no momento não nos importa o debate, bastando-nos o recorte em 'moralidades', uma das formas dos 'autos de devoção'.

\footnotetext{
${ }^{9}$ Foi não apenas autor de peças teatrais, mas ator, ensaiador, músico, talvez cenógrafo, e organizador das festas públicas e palacianas. Também foi identificado como ourives, autor da famosa Custódia de Belém, Mestre da Balança e representante da Casa dos 24 na Câmara de Lisboa. E, ainda, como mestre de retórica de D. Manuel e como alfaiate, o que é menos provável - talvez devendo-se esta atribuição ao caráter popular do seu nome, pertencente, por exemplo, também a um carpinteiro do século $\mathrm{XV}$, dentre outros.
} 
Por moralidades entendia-se, na Idade Média, os autos alegóricos destinados à doutrinação, personificando e tornando concretas idéias abstratas, como vícios e virtudes. Gil Vicente, ao incluir nessa rubrica também o mistério e o milagre - os outros espécimes medievais do teatro religioso, focalizando, respectivamente, situações-limite ou intervenções miraculosas dos santos e passagens bíblicas, notadamente dos Evangelhos e das prefigurações messiânicas do Velho Testamento -, já destacava a finalidade didática e moralizadora que lhes era comum. Assim, o único milagre que dele conhecemos, o Auto de S. Martinho (encenado, em 1504), nada tem de sobrenatural, mas, a modo de exemplo - o santo divide com um pobre a sua capa em um rigoroso inverno -, propugna a verdadeira e mais completa caridade, que consiste em dividir com os necessitados não apenas o que se possui de supérfluo, mas de essencial. E dos três mistérios, ${ }^{10}$ destaca-se o Auto dos Mistérios da Virgem, de 1515, reapresentado em1534.

${ }^{10}$ Gil Vicente escreveu mais dois desses espécimes: 1) Breve sumário da história de Deus, de 1527, que é o mais completo de todos, começando pela criação do mundo e terminando com a morte de Jesus; dá-lhe seqüência o Diálogo sobre a ressurreição de Cristo, também de 1527; 2) Auto da Cananéia, de 1534, que focaliza o episódio bíblico da cura de uma jovem possessa por Jesus, movido pela ardorosa fé da mãe dela e não pela intercessão dos apóstolos. É interessante observar-se que, aproximando-se do caráter alegórico das moralidades, esse auto personifica as Leis em pastoras, relacionando-se também com os pastoris. E, como em outros autos vicentinos, aproxima-se da carnavalização própria da cultura medieva, colocando em cena diabos não aterrorizantes. Cf., a propósito da classificação de peças vicentinas como 'mistérios', a obra de A. José Saraiva, Gil Vicente e o fim do teatro medieval (SARAIVA, 1981) e o verbete de Révah sobre Gil Vicente (in COELHO, 1973, vol. III, p. 1164-1168). 
Este, mais conhecido como Auto da Mofina Mendes, é sem dúvida um dos mais preciosos textos vicentinos. Trata-se de texto híbrido que, ao lado do mistério da concepção e de elementos pastoris costumeiros do ciclo natalino, põe em cena virtudes alegorizadas que dão claros ensinamentos da doutrina, o que é próprio das moralidades; e, ainda, fustiga os vícios da sociedade do tempo, inclusive através de episódios que se apresentam como espécimes profanos incluídos no Auto: o sermão burlesco com que um frade, aparentemente tresloucado, abre $o$ auto, e a farsa.da Mofina Mendes, personagem que passou inclusive a denominá-lo. Passaremos a seguir à observação, à luz da retórica e da poética, dos seus diferentes discursos, dos diversos recursos usados por Gil Vicente para doutrinar de forma agradável o auditório a quem se dirigia.

\section{A 'moralidade' da Mofina Mendes}

Levando em conta a sua dispositio, ${ }_{11}^{11}$ vemos que o Auto dos Mistérios da Virgem, que se vulgarizou como Auto da Mofina Mendes, é formado por quatro partes, claramente delimitadas: um Prólogo, constituído pelo discurso aparentemente desconexo de um frade, como se fosse amalucado o seu emissor; uma primeira parte, que

\footnotetext{
${ }^{11}$ Lembramos que a retórica clássica, tal como a conhecemos através de Aristóteles e do principal divulgador da Arte retórica no Ocidente, Cícero, se compõe de inventio (invenção ou descoberta das idéias necessárias à elaboração do discurso), dispositio (disposição das mesmas, estruturação), elocutio (semântica e figuras ou tropos escolhidos para melhor desenvolver a argumentação; estilo), memoria e pronuntiatio (que, em se tratando de sermões e peças teatrais, assumem importância ainda maior, dado a necessidade de não apenas saber-se de cor o texto, mas de usar a voz e os gestos adequados ao realce da mensagem).
} 
retoma o episódio bíblico da Anunciação a Maria; um intermezzo, correspondente à cena pastoril e profana, recriada a partir de historieta folclórica cuja origem remonta a um apólogo indiano, da Mofina Mendes; e uma segunda parte, sobre o Nascimento de Jesus, em que se unem o sagrado e o profano - não apenas pelo seu próprio significado, da encarnação divina para a redenção da humanidade, como também pelo discurso, ações e reações dos pastores, que com o Anjo gracejam e só depois de muita argumentação atendem ao seu apelo.

A unidade da composição é assegurada pelo motivo recorrente em todas as suas partes, apontando para a precariedade do conhecimento, das posses e do poder humanos contrastando com a grandiosidade infinita do divino. Assim é que, na parte inicial do prólogo, dentre outras críticas, é denunciada a presunção humana de conhecer "os secretos divinais / que estão debaixo da terra"12 - isto é, a capacidade de previsão de terremotos, à época inconcebível. Na primeira parte, lembra o anjo Gabriel em seu discurso à Virgem "que tudo a Deus é possível / e o que é mais impossível / lhe é o menos de fazer". ${ }^{13}$ No intermezzo, as palavras finais da Mofina Mendes sentenciam "que todo o humano deleite (...) há de dar consigo em terra" ${ }^{14}$ E na segunda parte alude a Fé à "cegueira geral"15 em que está imersa a humanidade. Portanto, através do jogo de contrastes entre os valores materiais e os espirituais, estes serão evidentemente valorizados em detrimento daqueles, como nos sermões. E o nascimento de Jesus, segundo a doutrina cristã, se apresenta como a ponte redentora, através da

12 VICENTE, 2002, vol. I, p. 113.

${ }^{13}$ VICENTE, 2002, vol. I, p. 120.

${ }^{14}$ VICENTE, 2002, vol. I, p. 126.

15 VICENTE, 2002, vol. I, p. 129. 
qual a onipotência divina faculta ao homem a possibilidade de sua religação a ela.

A fala inicial, do frade, a modo de um exórdio ou prólogo, ${ }^{16}$ teria por finalidade atrair a atenção e a simpatia do auditório e eliminar o caráter arbitrário de todo começo, bem como apresentar o plano do Auto, filiando-se, dessa forma, aos preceitos da retórica antiga ${ }^{17}$ para essa parte inicial do discurso. Já o referido monge cisterciense Alain de Lille, ao teorizar sobre a prédica em De arte praedicatoria, na esteira dos clássicos sentenciava que o pregador "deve captar a benevolência de seu auditório para com a sua própria pessoa através da humildade" ${ }^{18}$ Mas recomendava que o sermão não fosse exagerado, teatral. Nele não deveria haver "nem bufoneria, nem puerilidades, nem melodias cadenciadas ou versos bem torneados, que servem mais para encantar aos ouvidos que para formar os espíritos" ${ }^{19}$ Nisto consiste o afastamento maior de Gil Vicente em relação à 'seriedade' do sermão. Mas, ao incluir personagens risíveis em seu Auto (e não apenas neste que ora analisamos),

${ }^{16}$ Já demonstrara Aristóteles (s.d., p. 249), que os exórdios "desempenham o mesmo papel que os prólogos das peças teatrais e os preâmbulos dos poemas épicos".

${ }^{17}$ Como ensinava o Estagirita, o exórdio dirigido ao ouvinte tem por finalidade "obter a benevolência e provocar a cólera do mesmo, por vezes chamar-lhe a atenção, ou, pelo contrário, distraí-la, pois nem sempre é oportuno que o ouvinte esteja atento" (ARISTÓTELES, s.d., p. 250).

18 "Debet captare benevolentiam auditorum a propria persona per humilitatem"(P.L., t. 210, col. 113; a tradução acima é nossa).

19 "Nom debet habere verba scurrilia, vel puerilia vel rhythmorum melodial et consonantias, metrorum, quae potius fiunt ad aures demulcendas quam ad animum instruendum, quae praedicatio theatralis est et mimica, et ideo omnifarie contemnanda" (P. L., t. 210, col 112; traduzimos acima). 
foi certamente mais convincente que qualquer clérigo no ensinamento da doutrina e na conversão do público para a boa conduta religiosa. Isto porque o ensinamento através da sua arte se apresentava de modo prazeroso, unindo o docere ao delectare recomendado pelos antigos. E através da comicidade, como veremos, estabelece profundas lições ético-religiosas.

Temos, pois, que a atenção do auditório é alcançada através da comicidade inicial do discurso do frade, à primeira vista sem sentido mas que descamba em ferrenha sátira de costumes, e termina com a apresentação, lógica, das linhas gerais do Auto: seu título-tema, "dos mistérios da virgem", suas personagens principais (a Virgem e as Virtudes suas companheiras), a divisão do assunto (a Anunciação e o Nascimento de Jesus). Causa espécie, desde já, não ter sido a Mofina Mendes sequer mencionada nesse Prólogo, o que se justificaria por constituir um intermezzo, dotado de autonomia própria, podendo do Auto separar-se. Mas o que aconteceu é que essa figura fabulosa terminou por substituir a excelsa Virgem na intitulação da peça. Como veremos adiante, após conquistar o público através do riso provocado pelas suas insanidades ela termina por igualarse a Maria com a reflexão que finaliza o seu discurso, sobre a precariedade dos bens materiais.

Também o discurso 'amalucado' do frade chegou a ser considerado desnecessário à obra - o que não procede, uma vez que a crítica que percorre todo o Auto, aos valores do mundo material, nele já se apresenta de forma contundente. Temos de ter em mente que "nos meios mais educados ou em círculos institucionais, as exigências para atingir o riso através das tendências hostis devem disfarçar-se habilmente" ${ }^{\prime 20} \mathrm{E}$ que, além de pessoas eminentes, podem ser "objeto da comicidade e do chiste todos os valores, todas as instituições, todas as autoridades,

${ }^{20}$ MORAES, 1974, p. 28. 
todos os conceitos, todas as idéias" ou, na lição freudiana, "tudo o que representa 'superego' ${ }^{\prime \prime} .{ }^{21}$ Isto explicaria o fato de Gil Vicente ter colocado em cena uma figura cômica, para ludibriar inclusive a Inquisição, bem como para não melindrar a seleta platéia a que a peça se destinava - a corte de D. João III, como vimos.

O chiste, que se manifesta na enunciação do frade, se veicula por expressões sem sentido, como a apóstrofe "ó terra filha do barro", ${ }^{22}$ bem como, e principalmente, por um latim 'macarrônico', através do qual são nomeados obras e locais caracterizadores de personalidades dos mais variados campos, épocas e línguas do saber universal, como, por exemplo, "Salustius Catelinarum" ou "Seneca vandaliarum", ${ }^{23}$ etc. Da desencontrada pregação emerge a crítica aos "letrados de Rio Torto", ${ }^{24}$ - isto é, de fundamentação duvidosa - e aos pedantes de bom saber, citadores de livros como os "aqui alegados". ${ }^{25}$

Igualmente criticados são os frades de Santarém, que se ufanavam capazes de prever com exatidão a ocorrência de terremotos como o que abalara Lisboa em 1531. No entanto, a sua condição humana não lhes permitia nem sequer saber "em que hora há de nacer / ou que feições há de ter" os filhos que faziam. ${ }^{26}$ Com eles, são criticados todos aqueles que se dedicavam a predizer o futuro, comparados pejorativamente a minhotos: "o porvir não no sabeis / e quem nisso quer pôr peis / tem cabeça de minhoto".${ }^{27} \mathrm{E}$ a repreensão ao clero se estende,

\footnotetext{
${ }^{21}$ MORAES, 1974, p. 30.

22 VICENTE, 2002, vol. I, p. 112.

${ }^{23}$ VICENTE, 2002, vol. I, p. 112.

${ }^{24}$ VICENTE, 2002, vol I, p. 112.

${ }^{25}$ VICENTE, 2002, vol I, p. 113.

${ }^{26}$ VICENTE, 2002, vol I, p. 113.

${ }^{27}$ VICENTE, 2002, vol I, p. 112.
} 
ainda, à sua licenciosidade, abuso e irresponsabilidade, que resultavam em "enjeitados / filhos de clérigos pobres". ${ }^{28}$

A falibilidade da justiça humana é também denunciada, uma vez que a erudição dos juízes não lhes garante sabedoria: "nam é sesudo o juiz / que tem jeito no que diz / e nam acerta o que faz" ${ }^{29} \mathrm{E}$ aos avarentos é invocada jocosamente a pena infernal que os aguardaria: "nesta vida gozava / e no inferno cantava: / água Deos água / que lhe arde a pousada". ${ }^{30}$

Enfim, "a modo de pregação"31 - assumindo, pois, a sua condição de 'sermão burlesco', gênero teatral paródico corrente no medievo -, após as acirradas críticas impetradas através do cômico de palavras contra os pecados da soberbia e da avareza, contrários das virtudes da humildade e da caridade, o frade assume o papel do qual o incubiram: "introduzir / as figuras que hão de vir / com todo seu aparato". ${ }^{32}$ Completa, dessa forma, a sua função de prólogo, apresentando os elementos que compõem a peça, que, da mesma forma que um sermão, como vimos com Thomas de Galles, se divide em "partes convenientemente concordantes entre si", com análoga finalidade doutrinária e persuasiva: ${ }^{33}$ "Será logo o fundamento / tratar da saudação / e depois deste sermão / um pouco do nacimento / tudo per nova invenção".${ }^{34}$ A revelação a Maria da divina concepção seguida do nascimento do Menino-Deus são, pois, as duas partes em que se divide o Auto, insistindo-se no

\footnotetext{
28 VICENTE, 2002, vol I, p. 113.

${ }^{29}$ VICENTE, 2002, vol I, p. 112.

${ }^{30}$ VICENTE, 2002, vol I, p. 113.

31 VICENTE, 2002, vol I, p. 111.

32 VICENTE, 2002, vol I, p. 114.

33 Apud DAVY, 1931, p. 31; traduzimos.

34 VICENTE, 2002, vol I, p. 115.
} 
seu papel de arte que, comojá nos ensinava Aristóteles, apresenta o possível e o conveniente: "não compete ao poeta narrar exatamente o que aconteceu; mas sim o que poderia ter acontecido, o possível, segundo a verossimilhança ou a necessidade" ${ }^{35}$ Assim, se a matéria na qual se baseou é a Verdade bíblica, inquestionável para os cristãos, avisa reiteradamente o autor: "haveis de considerar / isto ser contemplação / fora da história geral / mas fundada em devação". ${ }^{36}$

Após apresentar as personagens principais - as alegorias das virtudes (Pobreza, Humildade, Fé e Prudência) e a Virgem, deixando de referir-se a $S$. José e à Mofina -, bem como as partes do auto, o frade refere-se aos cânticos que as antecederão, personificados através da indicação de suas indumentárias: "Domine labia mea / e Venite adoremus / vestido com capa alhea. / Trará Te Deum laudamus / d'escarlata um libré", etc. ${ }^{37}$ Conquanto o teatro vicentino não obedeça às regras do teatro greco-romano, no entanto pode-se aventar a hipótese de que a poética assim como a retórica aristotélica, mesmo que indiretamente, (in)formaram nosso autor. Senão vejamos como Aristóteles define o prólogo: "é uma parte da tragédia que a si mesmo se basta, e que precede o párodo (ou entrada do coro)" ${ }^{38}$ Os hinos personificados por Gil Vicente podem ser percebidos com função aproximada à do coro grego, uma vez que adiantam o que está por vir - a louvação e adoração do Senhor.

Sabemos que no teatro, principalmente no medieval onde os aparatos cênicos eram escassos ou mesmo inexistentes, as personagens são absolutamente fundamentais, sendo através

\footnotetext{
35 ARISTÓTELES, [s.d], p. 306.

36 VICENTE, 2002, vol I, p. 114.

37 VICENTE, 2002, vol I, p. 114.

${ }^{38}$ ARISTÓTELES, [s.d.], p. 312.
} 
da sua voz e gestos, além da indumentária típica ou simbólica, que os fatos se dão a conhecer. No Auto que estamos analisando, duas são as personagens centrais, que inclusive lhe disputam o título: Maria e a Mofina Mendes, sendo que, como apontamos anteriormente, esta sequer aparece na apresentação do fradeprólogo. Mas, do Intermezzo em que se insere - e que como tal apresentaria autonomia própria, servindo mais como elemento de distensão à seriedade do assunto a ser tratado no Auto e podendo deste separar-se -, terminou por dominar a cena, ficando no correr dos tempos a peça conhecida muito mais como sua que como dos "mistérios da Virgem" como a nomeara o autor através do frade..$^{39}$

São figuras aparentemente contrastantes: à graça outorgada por Deus à virtuosa Maria corresponde a desgraça que acompanha ou que é mesmo personificada pela Mofina, como indica o seu próprio nome, sinônimo de desditosa, importuna e outras adjetivações negativas. À primeira vista, uma éa outra às avessas: Maria apresenta-se acompanhada de virtudes que não são possuídas pela doidivanas Mofina, principalmente a prudência. Mas ambas se amalgamam na moralidade do discurso com que esta conclui, de forma inesperada, o seu aparecimento em cena, apontando para a vanidade dos bens materiais.

Nestas duas figuras, Gil Vicente funde admiravelmente a tradição sacra e a profana, heranças da tradição que o (in)formou. No seu trabalho relativo à inventio, a recriação que apresenta de Maria se pauta, evidentemente, na Bíblia, com ligeiros afastamentos - como, por exemplo, o fato de ela duvidar, por motivo de sua extrema humildade que a faz não se considerar digna de ser a mãe do Messias, do mensageiro divino, pedindo "sinal dos Céus". ${ }^{40}$ Já a Mofina Mendes remontaria a um

${ }^{39}$ VICENTE, 2002, vol I, p. 114.

${ }^{40}$ VICENTE, 2002, vol I, p. 120. 
'avadana' indiano do Pancatantra, ${ }^{41}$ do qual foram feitas traduções e versões várias, inclusive latinas e espanholas, através das quais foi divulgado na Idade Média também através de sermonários, nos quais o apólogo aparecia como 'exemplo'. Na tradição oral era corrente o provérbio "bilha de azeite por bilha de leite", aproveitado pelo dramaturgo que, seguindo as versões locais, apresenta a personagem com a bilha de azeite, fazendo-a reagir de maneira singular à sua queda.

Examinando-lhe a elocutio, vemos que na qualificação de Maria o Auto vicentino apresenta epítetos os mais dignificantes, como "Alta Senhora, ${ }^{42}$ que na prefiguração salomônica retomada se apresentava "alva sobre quantas foram / santa sobre quantas são". ${ }^{43}$ Tendo por adjuvantes as virtudes, S. José e os Anjos, e por oponente a humanidade pecadora, é a mãe do bom Pastor, Jesus Cristo, que sacrificaria a vida pelas suas ovelhas, sendo, assim, também cordeiro. Como tal, por extensão, é igualmente Pastora, no sentido metafórico-bíblico do termo. ${ }^{44} \mathrm{E}$ é nessa qualidade que se preocupa com as ovelhas desgarradas, constituídas pela humanidade cega, e tenta prepará-las para o grande Advento - a encarnação do Cristo -, tentando dissiparlhes as trevas, o "fogo tam apagado" em que estavam imersas, tentando iluminar o "tam escuro porto / de ũa cegueria geral" ${ }^{45}$

Mas os homens, inimigos da Pobreza e da Humildade, "são de mui perversa vea", e preferem "cama de flores / feita de prazer sonhado". ${ }^{46}$ Desdenhando a Prudência e a Fé,

\footnotetext{
41 "Coleção de fábulas e contos em sânscrito, compilados nos dois primeiros séculos da nossa era" (Vb) (LAROUSSE, vol. 18, 1998, p. 4412).

42 VICENTE, 2002, vol I, p. 118.

${ }^{43}$ VICENTE, 2002, vol I, p. 117.

${ }^{44}$ Cf, João, 10-11 (BÍBLIA, 1981, p. 1398).

${ }^{45}$ VICENTE, 2002, vol I, p. 129.

${ }^{46}$ VICENTE, 2002, vol I, p. 128-129.
} 
recusam lume para a "divina vela", a "eternal candea", a "santa vela da glória". ${ }^{47}$ E fazem Maria sentir-se em "terra alhea", como se comprova na fala da Humildade: "Deviam ter piedade / da senhora peregrina / romeira da cristandade / que está nesta escuridade / sendo princesa divina / pera exemplo dos senhores / pera lição dos tiranos / pera espelho dos mundanos / pera lei aos pecadores / e memória dos enganos". ${ }^{48}$

Os bens celestiais, luminosos, se apresentam, pois, completamente desdenhados pela humanidade imersa em trevas, corroborando o Evangelho joanino: "A luz brilha nas trevas / mas as trevas não a apreenderam". ${ }^{49}$ A oposição entre a luz e as trevas, entre os valores espirituais e os materiais, constitui, pois, a tensão estruturante do Auto, a exemplo do que ocorre no dito Evangelho.

Importa destacar ainda, a propósito, a fala de S. José, que denuncia a ignorância e a ambição desmedida dos homens, mostrando a inutilidade de a divina Pastora tentar redimi-los: "Senhora não monta mais / semear milho nos rios / que querermos por sinais / meter cousas divinais / nas cabeças dos bogios" ${ }^{\prime 50}$ Observe-se a utilização estilística de impossibilia ou adynata ${ }^{51}$ - "semear milho nos rios" - e da metáfora "bogios", para acentuar quão infrutífero seria tentar converter os homens, grosseiros e ignorantes como os referidos animais, ao cristianismo verdadeiro. A eles só interessam os bens materiais: "Mandai-

47 VICENTE, 2002, vol I, p. 128-129.

48 VICENTE, 2002, vol I, p. 129.

49 João, 1-5 (BÍBLIA, 1981, p. 1383).

50 VICENTE, 2002, vol I, p. 130.

${ }^{51}$ Como demonstrara Ernst Robert Curtius (1989, p. 144), a "enumeração de impossíveis", de origem antiga, era corrente na Idade Média, sendo então bem conhecidos os adynata virgilianos. 
lhe[s] acender candeas / que chamem ouro e fazenda / e vereis bailar baleas / porque irão tirar das veas / o lume com que s'acenda". ${ }^{52}$ Portanto, o mais difícil e penoso só é realizado para o alcance desses bens, perseguidos também pelos 'religiosos', numa evidente crítica ao clero sedento de poder e riquezas: " $\mathrm{E}$ a gente religiosa / manda-lhes velas bispais / a cera de renda grossa / os pavios de casais / e logo não porão grosa". ${ }^{53}$ Repare-se no anacronismo do termo "bispais", se o considerarmos não etimologicamente, mas em relação ao assunto do Auto, referente ao bispado que, enquanto instituição eclesial, só poderia ser posterior ao nascimento de Jesus. Condena-se, desta forma, a opulência das próprias autoridades clericais, ao tempo de Gil Vicente.

Quanto à Mofina Mendes, a mudança brusca do tom elevado da primeira parte do Auto para o tom rude do Intermezzo em que ela se insere já prepara, por si, a sua entrada em cena. Não possui adjuvantes, e o opositor é o seu próprio caráter e/ ou símbolo que personifica. É a "daninha pegureira", 54 "Mofina Mendez toda" ${ }^{55} \mathrm{Ou}$ seja, irresponsável e desgraçada ou a própria Desgraça, como, vale repetir, indica o seu nome. Disto resulta um caminhar da alegoria do nome para o tipo, expresso pelo temperamento da irresponsável pastora, e deste novamente à alegoria, última impressão que nos deixa.

Ao contrário da Virgem, é caracterizada por suas ações, através de verbos, muito mais que pintada estaticamente por adjetivos. E, enquanto símbolo, extrapola os limites do tempo e do espaço, como se percebe na resposta que o seu amo Paio Vaz

${ }^{52}$ VICENTE, 2002, vol I, p. 130.

${ }^{53}$ VICENTE, 2002, vol I, p. 130.

${ }^{54}$ VICENTE, 2002, vol I, p. 124.

${ }^{55}$ VICENTE, 2002, vol I, p. 125. 
dá a André, que o indaga sobre o tempo que a Mofina o serve: "Bem trinta anos haverá / ou creio que os faz agora / mas sessego nam alcança / nam sei que maleita a toma. / Ela deu o saco em Roma / e prendeu el rei de França / agora andou com Mafoma / e pôs o Turco em balança" . ${ }^{56}$ Note-se a inverossimilhança, desculpável como elemento de provocação do riso nas comédias, presente no fato de ser Paio Vaz um rude campesino que, sem nenhum meio rápido de comunicação, inexistente à época, à maneira de um repórter de hoje saber das façanhas da Mofina, que, também sem nenhum meio rápido de transporte, esteve em lugares tão afastados e participando de acontecimentos quase concomitantes - o que lhe confirma a condição de alegoria simbólica, aliás referendada pelo verbo 'amofinar': aos "Turcos amofinava / e a Calros césar servia". ${ }^{57}$ Aliás, Paio Vaz, apesar da sua rudeza, inclusive se expressa em latim, ao informar que o exército turco "Receou a guerra crua / que o césar lhe prometia / entances per aliam via / reverte sunt in patria sua / com quanta gente trazia" ${ }^{58}$

Enquanto personagem-tipo, Mofina Mendes caracterizase pelo non-sense, cômica de caráter e situação. É a anti-pastora, completamente despreocupada do rebanho que tem sob sua guarda: "A boiada nam vi eu / andam lá nam sei per $u$ / nem sei que pacigo é o seu / / nem as cabras nam nas vi / samicas c'os arvoredos / mas nam sei a quem ouvi / que andavam elas per i / saltando pelos penedos". ${ }^{59}$ Ao seu amo presta uma verdadeira "conta de negregura", ${ }^{60}$ exigindo-lhe, apesar de lhe ter dizimado o rebanho, o seu soldo. Então é paga com um pote de azeite e,

\footnotetext{
56 VICENTE, 2002, vol I, p. 121.

57 VICENTE, 2002, vol I, p. 121.

58 VICENTE, 2002, vol I, p. 122.

${ }^{59}$ VICENTE, 2002, vol I, p. 123.

${ }^{60}$ VICENTE, 2002, vol I, p. 123.
} 
a bailar com ele à cabeça, a exemplo do seu paradigma apologal, tece os mais incríveis sonhos de prosperidade e realização pessoal, que culminam com o poder casar-se "rica e honrada".${ }^{61}$ Isto também constitui marca de comicidade, já que se trata de uma velha, que (des)serve ao seu amo por cerca de trinta anos, com ilusões de uma jovem donzela. Mas do sem-sentido de suas ações e sonhos emerge o supra-senso, através da lição sobre a vanidade dos bens materiais, que termina por perpetrar ao ver perdida a sua única posse, que se espatifou ao chão: "Por mais que a dita m'enjeite / pastores nam me deis guerra / que todo o humano deleite / como o meu pote d'azeite / há de dar consigo em terra". ${ }^{62}$

Dessa forma a Mofina deixa de ser risível e considerada inferior, propiciando a reflexão do público sobre a angustiante condição humana e alcançando-lhe a solidariedade. Passa a assemelhar-se, então, a Maria, "humana e divina rosa", ${ }^{63}$ mãe d'Aquele cujo reino não é deste mundo, sendo ambas por este marginalizadas. A mesma verdade profunda as une: a do reconhecimento de que tudo o que o senso comum valoriza é perecível, passageiro. O que nos remete às sábias palavras de João Guimarães Rosa: "por onde, pelo comum, pode-se corrigir o ridículo ou o grotesco, até elevá-los ao sublime; seja daí que seu entre-limite é tão tênue". Com o grande escritor brasileiro das Gerais resta-nos perguntar: "E não será esse um caminho por onde o perfeitíssimo se alcança? Sempre que algo de importante e grande se faz, houve um silogismo inconcluso, ou, digamos, um pulo do cômico ao excelso". ${ }^{64}$

\footnotetext{
${ }^{61}$ VICENTE, 2002, vol I, p. 125.

${ }^{62}$ VICENTE, 2002, vol I, p. 125-126.

${ }^{63}$ VICENTE, 2002, vol I, p. 117.

${ }^{64}$ ROSA, 1969, p, 11.
} 
Diante da comprovação do sentido maior do cômico, através da Mofina como também do frade-prólogo, podemos concluir, novamente com o escritor mineiro: "não é o chiste rara coisa ordinária; tanto seja porque escancha os planos da lógica, propondo-nos realidade superior e dimensões para mágicos novos sistemas de pensamento". Utilizando-lhe as palavras podemos ainda dizer a propósito dos personagens vicentinos: "o não-senso, crê-se, reflete por um triz a coerência do mistério geral, que nos envolve e cria". E concluir: "A vida também é para ser lida. Não literalmente, mas em seu supra-senso. E a gente, por enquanto, só a lê por linhas tortas". ${ }^{65}$

Portanto, da importância do cômico - de caráter, de palavra ou de situação - decorreria uma primeira explicação para a mudança ocorrida no título do Auto. A substituição do elemento sacro pelo profano se desvela não tanto como modificação, mas variação do original, uma vez que a Mofina, à primeira vista contrastante com a Virgem, acaba por se tornar a ela semelhante, na condenação do "humano deleite", realizando-se, dessa forma, um "pulo do cômico ao excelso". E a comicidade da figura da (anti)pastora, pelo seu caráter novidadeiro, humano, revitalizante - posto que simbólico e/ ou até mesmo alegórico - se faz preferível ao hieratismo, à estaticidade da santa, para os espectadores e leitores que pelos séculos se têm deleitado com a obra vicentina. Pelo mesmo motivo é valorizado o discurso 'amalucado' do frade que, como a Virgem e a Mofina, afastando-se dos valores instituídos pelo senso comum, destes estabelece a crítica, filiando-se à Verdade maior, não fundada em aparências.

Desculpa-se, dessa forma, a inclusão do riso em um 'Auto de devoção', que, se desobedeceu à seriedade recomendada pelos teóricos da arte de pregar, alcançou / alcança certamente o

${ }^{65}$ ROSA, 1969, p. 3-4. 
objetivo maior de qualquer sermão: ensinar a doutrina e seus valores, bem como incentivar à prática de uma vida virtuosa os receptores que pelos séculos se têm deleitado com a obra vicentina.

\section{Referências}

ARISTÓTELES. Arte retórica e arte poética. Trad. Antônio Pinto de Carvalho. Rio de Janeiro: Edições de Ouro, [s.d.].

BÍBLIA DE JERUSALÉM (A). Edição em língua portuguesa sob a coordenação de Gilberto da Silva Gorgulho et alii. S. Paulo: Edições Paulinas, 1981.

CURTIUS, Ernst Robert. Literatura europea y Edad Media latina. Trad. de Margit Frenk Alatorre y Antonio Alatorre. 5. reimp. en España. México / Madrid: Fondo de Cultura Económica, 1989.

CARVALHO, Joaquim de. Os sermões de Gil Vicente e a arte de pregar. Separata da revista Ocidente, Lisboa, números 124, 125 e 126, p. 66-72, 1948.

DAVID, M. M. Les sermons universitaires parisiens de 123-1231. Contribution a l'histoire de la prédication mèdievale. Paris: Librairie Philosophique J. Vrin, 1931.

LAROUSSE CULTURAL (Grande enciclopédia). Vol, 18. São Paulo: Nova Cultural, 1998.

MALEVAL, Maria do Amparo Tavares. A propósito de um título vicentino. Boletim Informativo do Centro de Estudos Portugueses da USP, São Paulo, ano 9, n. 12, p. 31-39, jul.-dez. 1983.

. Gil Vicente. MOISÉS, Massaud (Org.). A literatura portuguesa em perspectiva. Vol. I - Trovadorismo. Humanismo. São Paulo: Atlas, 1992.

. Fernão Lopes e a retórica medieval. Niterói: EdUFF, 2010.

MORAES, Oswaldo Domingues de. Freud: dos chistes ao cômico. 
Revista de cultura Vozes - O riso e o cômico, Petrópolis, p. 28-30, 1974. RÉVAH, I. S. Vicente, Gil (vb). COELHO, Jacinto do Prado. Dicionário de literatura - brasileira, portuguesa, galega e estilística literária. 3. ed. Porto: Figueirinhas, 1973. Vol 3, p. 1164-1169.

ROSA, João Guimarães. Tutaméia. 3. ed. Rio de Janeiro: José Olímpio, 1969.

SARAIVA, António José. Gil Vicente e o fim do teatro medieval. 3. ed. Lisboa: Bertrand, 1981.

VICENTE, Gil. As obras de Gil Vicente. Direcção científica de José Camões. Vols. I e II. Lisboa: Centro de Estudos de Teatro, Imprensa Nacional / Casa da Moeda, 2002.

\section{Resumo}

Gil Vicente, considerado o 'criador' do teatro português, foi um grande conhecedor da arte de pregar medieval, que resultou da confluência da retórica clássica com a tradição exegeta e concionatória judaico-cristã. Chegou inclusive a escrever sermões sérios ou jocosos, mas sempre revestidos de caráter moralizante, como o 'Sermão de Abrantes', encomendado pela franciscana rainha D. Leonor, 1506. Em suas 'moralidades', como denominou as peças revestidas de caráter religioso, demonstrou claramente a utilização das técnicas e da finalidade da prédica, de doutrinação e conversão para uma vida virtuosa. Pretendemos observar, no 'Auto dos Mistérios da Virgem', que se popularizou como 'Auto da Mofina Mendes', re(a)presentado nas matinas do Natal de 1534 ao rei D. João III, os recursos retóricos que o aproximam do sermão, seu intuito de ensinar de forma agradável a doutrina e de fustigar os vícios da sociedade do seu tempo e do homem de todos os tempos. 


\section{Résumé}

Considéré comme le 'créateur' du théâtre portugais, Gil Vicente fut un grand connaisseur de l'art médiéval de prêcher, au confluent de la rhétorique classique et de la tradition exégétique et concionatoire judéo-chrétiènne. Il a en outre écrit des sermons sérieux ou plaisantes, mais toujours revêtus d'un caractère moralisant, comme le 'Sermão de Abrantes', commandé par la reine franciscaine D. Leonor, en 1506. Dans ses 'moralités', comme il a dénommé les pièces à caractère religieux, il a démontré nettement l'utilisation des techniques et la finalité de la prédication, en tant que doctrine et conversion à une vie vertueuse. Nous avons l'intention d'observer, dans l' 'Auto dos Mistérios da Virgem', plus connu comme 1 'Auto da Mofina Mendes', représenté dans les matines du Noël de l'année 1534 au roi D. João III, les recours rhétoriques qui le rapprochent du sermon et comment s'y exprime le souci dagrémenter l'enseignement de la doctrine et de fustiger les vices de la société de son temps et de l'homme de tous les temps. 